\title{
Analysis of solar photovoltaic energy potential in Brazilian hydroelectric reservoirs through floating panels
}

\author{
Francielle da Rocha Santos ${ }^{1}$ \\ https://orcid.org/0000-0002-0389-7461 \\ Juliana D'Angela Mariano', \\ https://orcid.org/0000-0002-2740-2814 \\ Jonas Abilio Sestrem Junior ${ }^{1}$ \\ https://orcid.org/0000-0002-8520-8235 \\ Jair Urbanetz Junior ${ }^{1}$ \\ https://orcid.org/0000-0001-9355-1730
}

1 Universidade Tecnológica Federal do Paraná - UTFPR - Curitiba, Paraná Brasil;

Received: 2018.11.05; Accepted: 2019.07.26.

* francielleroch@hotmail.com; Telefone: +55 041-998811569.

\section{HIGHLIGHTS}

- The main hydroelectric power plant in Brazil are presented.

- An overview of the power generated by floating photovoltaic panels is given.

- The calculation on four reservoirs are is shown.

- Several variables are brought and analyzed which demonstrated the benefits of type of energy.

Abstract: Sustainability, a concept used to exploit natural resources without harming future generations, is being applied to power generation. In Brazil, the main source of electric energy comes from hydroelectric plants, due to abundant water resources. However, the implementation of these plants causes irreversible impacts on the environment and society. On the other hand, the impacts caused by photovoltaic panels are considerably smaller in the construction phase and zero in the operation phase. This article describes the impacts generated by hydroelectric power plants and gives an overview of the power generated by floating photovoltaic panels using $10 \%$ of the area of the reservoirs of the largest hydroelectric power plants in Brazil. The results demonstrate a better efficiency of the 
photovoltaic panels in the water, which cools them, increasing their efficiency. Furthermore, photovoltaic panel power generation amount is higher than compared the annual power generation of three out of four hydroelectric plants analyzed. In addition, adding solar energy to the reservoirs would save infrastructure costs, considering that energy can be made available through substation infrastructure and existing power transmission systems.

Keywords: hydroelectric plant, photovoltaic power, floating panel.

\section{INTRODUCTION}

The term "sustainable" has been used in recent years and is defined as a way to meet current demands, avoiding depletion of natural resources for future generations. In this sense, in case to consider something sustainable, it is necessary to estimate current and future needs, relating to how the funds were used in the past, how they are being used now and how they will be used in the future [1].

Together with this concept of preservation and development of living beings, it can be considered that energy has been engaged to achieve sustainable development through renewable resources. Energy is essential to eradicate poverty, increase human welfare and raise life standards [2].

In the global scenario, the energy sector is suffering a moment of transition, with the increase of sustainable development. In the last decades, sustainability has been a concern in many countries and sectors, and this new factor already plays a key role when it comes to assessing and comparing different energy sources and technologies for the country's electricity system.

In recent years, Brazil started to include alternative energy sources, such as biomass originated mainly from sugarcane bagasse, as well as wind energy and photovoltaic energy from solar radiation, at lower scales.

However, hydroelectric plants, originating from renewable primary sources, are the largest sources of energy in Brazil, due its great potential.

Hydroelectric plants present several benefits, mainly low operating costs and renewable energy source. However, hydropower requires large areas for reservoir construction, as well as environmental and social impacts caused by flooding, population displacement, loss of fauna and flora, insect proliferation, and greenhouse gas emissions.

The construction of hydroelectric plants cause several damages and the analysis of these impacts should be carried out in a way that better represents the interests of society [3].

Although hydroelectric plants are believed to generate energy without the emission of greenhouse gases, this opinion has been changed. [4] Researches demonstrate that reservoirs cover $500,000 \mathrm{~km}^{2}$ worldwide and emit 20 million tonnes of methane $(\mathrm{CH} 4)$ annually. Dams in tropical areas emit more $\mathrm{CH} 4$ than dams in temperate areas, due to the climate and vegetation type.

The release of carbon $\mathrm{CO} 2$ occurs when the reservoir is already full, with the beginning of vegetation decomposition, impacting Power generation. Thus part of the $\mathrm{CO} 2$ is transformed into methane by bacteria and the other part can be oxidized in the depletion zone, i.e. a marshy area that is exposed around the edge of the reservoir whenever the water is withdrawn for power generation during the dry season, intensifying global warming [5].

The large reservoirs and higher power levels of hydroelectric plants are concentrated in four regions of Brazil: South, Southeast, North and Northeast. Regarding the size of the reservoir, the largest are concentrated in the north and northeast, however the largest power generation plant is in southern Brazil.

In order to exploit these reservoirs to produce electric energy, it is possible applying the technology of floating photovoltaic panels in the reservoirs, in order to optimize the environmental impacts already caused in its construction and generate even more electric energy. 
Four Brazilian plants were considered for the purpose of this research paper. The Sobradinho, Tucuruí, Balbina and Itaipu plants, and their areas will be used in the proposed study.

\section{Sobradinho Hydropower Plant}

The Sobradinho plant started operations in the decade of the 1970s, in the state of Bahia, in northeastern Brazil. It has six turbines generating electricity and a potential of 1,050 megawatts (MW).

Its lake covers an area of $4,214 \mathrm{~km}^{2}$, with the expropriation of 26 thousand properties and compulsory displacement of more than 72 thousand people, including the relocation of four cities [6].

Studies related to the climate of the city of Sobradinho before and after the construction of the reservoir [7] indicate that the climatic parameters underwent substantial variations in the following years of formation of the lake. In addition, the most significant changes were air humidity and wind intensity. Considering the Sobradinho lake is a determining factor and that influences the climatic variation in the region, the situation becomes more critical in drought periods [8].

\section{Tucuruí Hydropower Plant}

Tucuruí Hydroelectric Power Plant, in the State of Pará has a reservoir of $2,850 \mathrm{~km}^{2}$ and an installed capacity of 8,370 MW.

It was built between 1975 and 1984, when there was no major concern for the environment. This plant was built on a submerged forest, and after flooding it released toxins that corrode the turbines, producing methane and generating conditions for mercury metallization. The decomposition of the vegetation also caused the emission of carbon dioxide, contributing to the worsening of the greenhouse effect [9].

There have been impacts caused by Mansonia mosquitoes, which can transmit several arboviruses and are vectors of parasitic worms that cause elephantiasis.

Generally, the local populations suffer the main impacts, while the rewards mainly benefit the large urban centers [10].

The dam has flooded part of three Indian reservations, its transmission lines isolated four other tribes, as well as damaged the indigenous areas downstream of the river, due to water pollution [11].

\section{Balbina Hydropower Plant}

The construction of hydroelectric plant Balbina began in the decade of 1980s, going into operation in 1989, in Rio Uatumã, Amazonas, flooding 2360 km², producing $250 \mathrm{MW}$.

The construction originated numerous environmental impacts, flooding an extensive area of native forest; altering the chemical composition of the water, generating the corrosion of the turbines, besides the organic matter decomposition; and finally interrupt the life cycle of several species of flora and fauna [12].

The watershed of Balbina is eight times larger than the dam area, this shows an inability for hydroelectric development. Comparing with the Itaipu plant, whose reservoir area is 1350 $\mathrm{km}^{2}$, the Paraná River basin, which supplies the Usina, has an area of $820,000 \mathrm{~km}^{2}$ [13], i.e. 600 times greater than the reservoir.

\section{Itaipu Hydropower Plant}

The world's largest power generation plant is located between Brazil and Paraguay, called the Itaipu Binational Hydroelectric Power Plant, with an installed capacity of 14,000 MW, providing about $15 \%$ of the energy consumed in Brazil and $75 \%$ of energy consumed in Paraguay. 
The impacts resulting from the construction and formation of the Itaipu Binacional Reservoir generated displacement of the population, loss of natural patrimony with the flood of Salto das Sete Quedas Falls and negative effects on the fauna and flora. The reservoir has $1,350 \mathrm{~km}^{2}$ with 20 generation units in operation. In 2016 it surpassed the Three Gorges Plant in China, returning to be the largest power plant in the world, producing more than 98.8 million megawatts / hour.

Although all the impacts that the reservoirs cause, this plant differs from the others mentioned, as it was able to bring advantages to the local population, improving the quality of life and, in general, benefiting Brazil and Paraguay.

The size of the flooded area to obtain the reservoir generally occupies many kilometers $(\mathrm{km})$, however, more important than the area, are the fertile lands that shelter diverse ecosystems that will be submerged, destroying natural habitats of numerous species. Many of these species of fauna and even flora do not survive in other environments.

A renewable option for the generation of energy is through solar radiation. Unlike hydroelectric power, photovoltaic can be installed in existing buildings, such as roofs and facades.

One of the problems for the development of photovoltaic power on a large scale in Brazil are the high cost of equipment for implementation, since most of them is obtained through imports; the lack of awareness of the improvements that a clean and renewable source provides and the lack of public policy to promote the integration of the energy generated by customers in electricity distribution companies [14].

In recent research the photovoltaic energy is being used in power plants through floating panels, generating energy even in periods of drought.

Floating photovoltaic panels

Floating photovoltaic panels can be used to preserve large areas of land, being installed in bodies of water such as oceans, lakes, ponds, reservoirs and other water bodies. These generators are usually made of polyethylene, a totally recycled material, which supports corrosion and high levels of solar radiation [15].

Floating photovoltaic solar panels have numerous advantages compared to conventional installed solar panels, including fewer obstacles to block sunlight, convenient energy efficiency, higher power generation efficiency due to their lower temperature under panels [15].

The temperature of the solar panels has a daily change in operation and the lack of cleaning can also influence, causing losses in its efficiency. However, lake water provides the cleaning of photovoltaic panels, leading to better efficiency.

There is also the benefit of installing floating panels in artificial reservoirs of hydroelectric plants, because the energy can be distributed using the existing transmission infrastructure. The connection of a solar array to the existing grid would save transmission infrastructure costs [16].

The relation between water and photovoltaic panels is mutually beneficial. Besides the photovoltaic panels suffer cooling and cleaning of the water, and thus generate more electricity, they also reduce evaporation and the growth of algae, as a consequence of the shadowing (Figure 1).

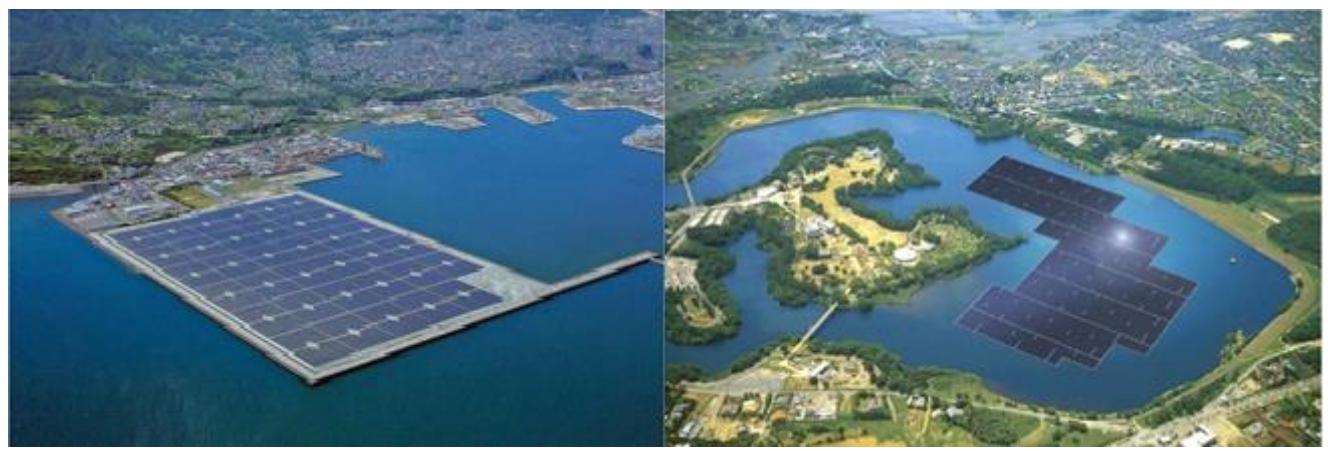

Figure 1: Floating solar power plants [15]. 
The average efficiency of floating solar panels is $11 \%$ higher compared to common solar panels [17] due to the cooling of the modules caused by the water.

In view of all the advantages presented, considering that hydroelectric plants have disadvantages in the periods of drought, when there is a reduction of the levels of the reservoirs and aiming an improvement of the energy potential, this article makes a perspective of the application of floating photovoltaic systems for power generation installed in $10 \%$ of the reservoirs of large hydropower plants in Brazil, presented below, highlighting its potential for using this technology.

\section{MATERIAL AND METHODS}

The projection of photovoltaic energy generation was performed considering only $10 \%$ of the area of the reservoirs of large Brazilian hydroelectric plants in relation to the flooded area.

To perform the calculations, It was considered modules of polycrystalline silicon of 320 $\mathrm{Wp}$ and area of $1.95 \mathrm{~m}$ of AXITEC of German manufacture. Equation 1 is described by [18].

N_mód= 『Área】_disp/ 『Área】_mód

Where $\mathrm{N}$ is the number of modules, Areadisp is the area of the plant on the area of each module, Areamód.

After the result of the number of modules, it is calculated the peak power of the panel (Equation 2). According to [18] the power of each module is multiplied by the number of modules.

P_Fv=P_(mód ) x N_mód

Where PFv is the photovoltaic potential, Pmód is the power of each module and Nmód is the number of modules.

The annual energy can be calculated through equation 3 based on the work of [16].

$E=\left(P \_F V \times H \_\right.$tot $\left.\times P R\right) / G \times 365$

Where $\mathrm{E}$ is the annual energy to be generated ( $\mathrm{kWh} /$ day), Htot is the incident solar irradiance in ( $\mathrm{kWh} / \mathrm{m}^{2}$.day), PR is the Performance Ratio (typically between $70 \%$ and $80 \%$ ), $\mathrm{G}$ is the irradiance $\left(1,000 \mathrm{~W} / \mathrm{m}^{2}\right)$ and 365 is the total number of days within a year.

In relation to the Htot values, the solar irradiance values were used in the horizontal plane of each plant, according to the latitude of each site. As a result, the annual average values presented by Htot were applied to the cities of Tucuruí in the state of Pará, Sobradinho, Bahia State, Presidente Figueiredo, in the state of Amazonas and Foz do Iguaçu, in the state of Paraná, which were collected through the Brazilian Atlas of Solar Energy [19].

The performance ratio considered for this study was $75 \%$, typical values used in the development of photovoltaic systems [20].

\section{RESULTS}

With the reservoir areas of the plants it was possible to extract the $10 \%$ to perform the area calculation using equation 1.

For the calculation of the annual energy perspective generated by the floating panels, the data of the Brazilian Atlas of Solar Energy [19] was used in the horizontal plane, identifying the Htot according to the location of the plants. The Htot values were 5.95; 4.68; $4.52 ; 4.78 \mathrm{kWh} / \mathrm{m}^{2}$ per day for Sobradinho, Tucuruí, Balbina and Itaipu, respectively. These values were applied in equation 3 and are described in Table 1. 
Table 1: Photovoltaic potential in hydroelectric reservoirs

\begin{tabular}{|c|c|c|c|c|c|c|c|}
\hline $\begin{array}{l}\text { Hydropower } \\
\text { Plant }\end{array}$ & $\begin{array}{l}\text { Reservoir } \\
\text { area }\left(\mathrm{km}^{2}\right)\end{array}$ & $\begin{array}{c}\text { Installed } \\
\text { Power } \\
(\mathrm{MW})\end{array}$ & $\begin{array}{c}\text { Energy } \\
\text { Generated- } \\
2015 \\
\text { (GWh) }\end{array}$ & $\begin{array}{c}\text { Energy } \\
\text { Generated- } \\
2016 \\
\text { (GWh) }\end{array}$ & $\begin{array}{l}\text { Area of } 10 \% \\
\qquad\left(\mathrm{~m}^{2}\right)\end{array}$ & $\begin{array}{c}\text { Installed } \\
\text { PV } \\
\text { power } \\
\text { (GWp) }\end{array}$ & $\begin{array}{c}\text { Energy } \\
\text { generated } \\
\text { (GWh) }\end{array}$ \\
\hline Sobradinho & 4,214 & 1,050 & 25,080 & 20,831 & $421,400,000$ & 69.15 & 112,632 \\
\hline Tucuruí & 2,850 & 8,370 & 35,497 & 25,792 & $285,000,000$ & 46.76 & 59,906 \\
\hline Balbina & 2,360 & 250 & 1,080 & 479 & $236,000,000$ & 38.72 & 47,910 \\
\hline Itaipu & 1,350 & 14,000 & 89,215 & 103,098 & $135,000,000$ & 22.15 & 28,983 \\
\hline
\end{tabular}

Table 1 also shows the characteristics of the hydroelectric plants analyzed, as well as the energy produced in the years 2015 and 2016.

The energy generated in the years 2015 and 2016 by Sobradinho, Tucuruí, Balbina and Itaipu Plants are compared with the energy perspective generated by the floating photovoltaic panels and presented in Figure 2.

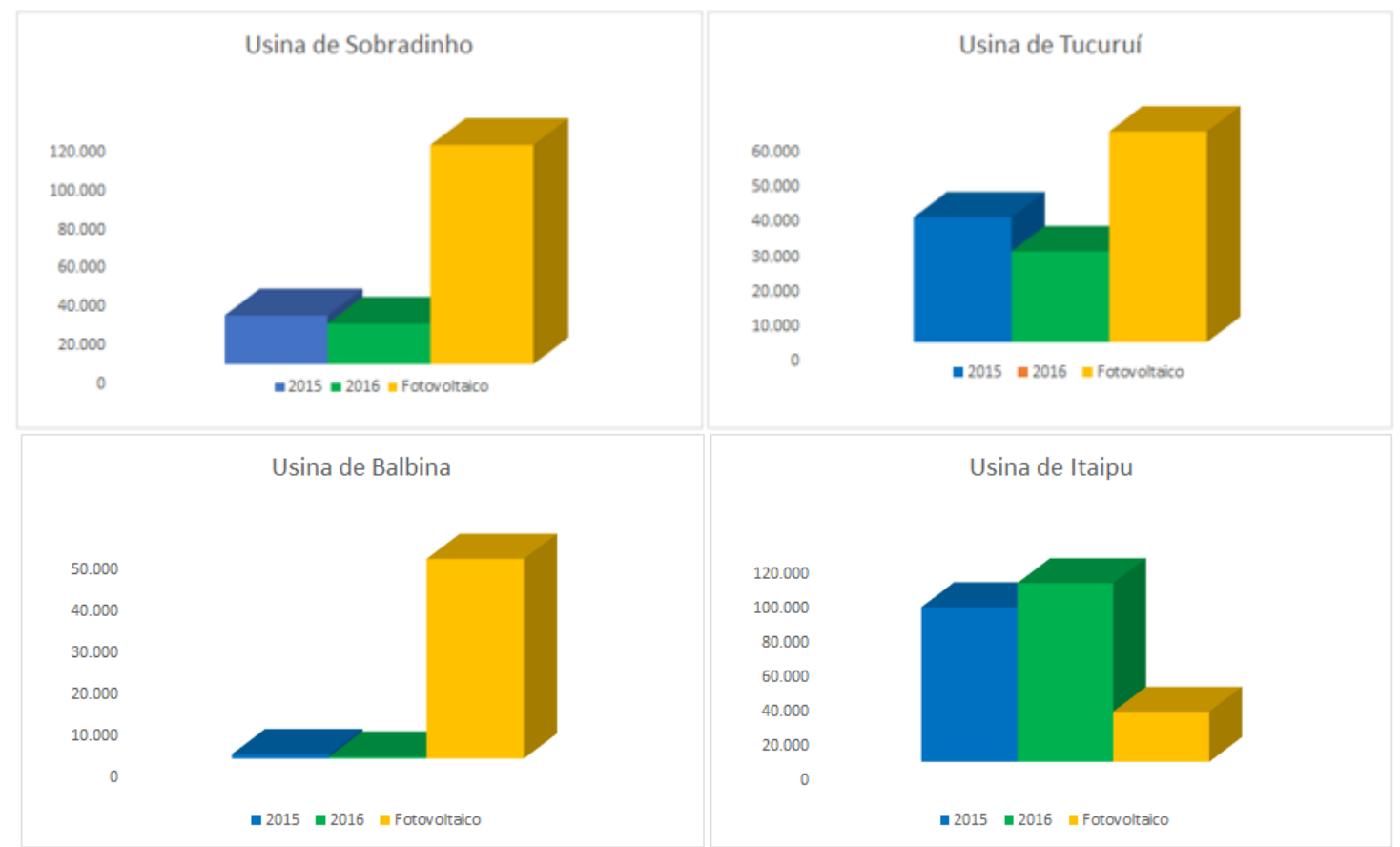

Figure 2: Annual power in the plants and the perspective of photovoltaic energy

The results show that in the Sobradinho, Tucurui and Balbina plants, they could present a significant increase in energy production with the insertion of the photovoltaic floating panels proposed by this study, which could surpass the real values of energy generated annually. The best result of the photovoltaic generation was for the Balbina Plant, considering that it has one of the largest reservoirs in Brazil, but it generates very little electricity. However, the Itaipu Power Plant, the largest power plant in the world in terms of power generation, even though there is an increase in its electricity production, only the proposed PV System would not exceed the generation of the plant itself, as occurred in the other hydroelectric plants analyzed to the fact that the Itaipu Plant reservoir is proportionally smaller than the others.

\section{CONCLUSION}

Hydroelectric plants are renewable energy sources and have a low cost in their operation phase, but it is necessary a great investment for implementation, in addition to 
social and environmental impacts. If the project of a hydroelectric plant is not well structured, these impacts may be even greater.

In this sense, these hydroelectric plants are vital for the Brazilian electrical system. However, these and other large hydroelectric plants have quite significant implementation impacts, therefore increasing its Power generation through the installation of photovoltaic panels floating in part of its reservoirs is a way to mitigate the impact caused, in addition to reducing the nerd of flooding new areas.

Brazil is a country with great availability of water sources, but some plants have huge reservoirs, which, however, generate low levels of energy. Thus, for a better use of these areas, the implementation of floating panels in the reservoirs of hydroelectric power plants, besides a socio-economic-environmental sustainable plan is also an option that is very favorable in the production of energy, due to the sustainable characteristics source.

According to the results shown in this research, in the Balbina hydroelectric plant, there would be an increase of sixty times in relation to the actual energy generated annually. The Sobradinho and Tucuruí mills would have an increase of four and two times the real value respectively. It should be noted that these values correspond to only $10 \%$ of the reservoirs, and may have higher numbers in larger percentages of these areas. Another benefit of the installation of floating panels would be the cost avoided with the infrastructure related to transmission lines and substations, considering that they are already in operation in the hydroelectric dams.

In the case of the Itaipu plant it would have a significant increase in energy production, but would not be higher than the actual energy levels. This is due to the fact that this plant was well planned and designed, and with it became the largest power plant in the world.

The results presented by this study show that even with the use of only $10 \%$ of the areas of these plants analyzed, considering the application of floating photovoltaic systems as a strategy to expand electric energy production, the use of this technology is viable in both technical and economic aspects, reducing demand for construction of large hydroelectric plants.

\section{REFERENCES}

1. Mikhailova, I. Sustentabilidade: evolução dos conceitos teóricos e os problemas da mensuraçãoprática. Revista Economia e Desenvolvimento, ํㅜ 16, 2004.

2. Vera, I; Langlois, I. Energy indicators for sustainable development. Energy, n. 32, p. 875-882, 2007.

3. Fearnside, P. M. Análisis de los principales proyectos hidro-energéticos em la región amazónica. Derecho, Ambiente y Recursos Naturales (DAR) \& Centro Latinoamericano de Ecología Social (CLAES), Lima, Peru. 55 p. 2014.

4. Bastviken, D.; Tranvik, J. L.; Downing, A. J.; Crill, M. P.; Enrich-Prast, A. Freshwater Methane Emissions Offset the Continental Carbon Sink. Science, [s.l.], v. 331, n. 6013, p.50-50, 6 jan. 2011. American Association for the Advancement of Science (AAAS). http://dx.doi.org/10.1126/science.1196808.

5. Fearnside, P. M. Hidrelétricas como "fábricas de metano": O papel dos reservatórios em áreas de floresta tropical na emissão de gases de efeito estufa. Oecologia Brasiliensis, [s.l.], v. 12, n. 01, p.116-129, ago. 2008. http://dx.doi.org/10.4257/oeco.2008.1201.11

6. Pereira, V. R. M. O papel da igreja na resistência camponesa de Sobradinho. Dissertação de Mestrado em Ciências Sociais. Salvador: Universidade Federal da Bahia- UFBA, 1987.

7. Correia, F. M.; Dias, S. F. A. da. Efeito do Lago de Sobradinho no clima local: uma análise numérica e observacional. Anais do XI Congresso Brasileiro de Meteorologia, 2000. p. 1739-1748.

8. Garcia, V. A.; Oliveira, A. C. E. De; Silva, P. G.; Costa, P. P. Da; Oliveira, A. L. de. Disponibilidade Hídrica e volume de água outorgado na micro-bacia do Ribeirão Abóbora, 
Município de Rio Verde, Estado de Goiás. Caminhos de Geografia, Uberlândia, v. 8, n.22, P. 97-106, set. 2007.

9. Silva, J. P. da. Usinas hidrelétricas do século XXI: empreendimentos com restrições à hidroeletricidade. Revista Engenharia. 2014.

10. Fearnside, Philip M. Environmental Impacts of Brazil's Tucurui Dam: Unlearned Lessons for Hydroelectric Development in Amazonia. Environmental Management, [s.I.], v. 27, n. 3, p.377-396, 1 mar. 2001. Springer Nature. http://dx.doi.org/10.1007/s002670010156

11. Fearnside, P. M. Análisis de los principales proyectos hidro-energéticos em la región amazónica. Derecho, Ambiente y Recursos Naturales (DAR) \& Centro Latinoamericano de Ecología Social (CLAES), Lima, Peru. 55 p. 2014.

12. Silva, J. P. da. O ecologismo e o economismo das usinas hidrelétricas. In Anais do VI Seminário Nacional da Gestão da Informação e do Conhecimento no Setor de Energia Elétrica, 2005.

13. Itaipu. Bacia do Rio Paraná. Disponível em:

https://www.itaipu.gov.br/energia/bacia-do-rio-parana> Acesso em: 09 dez. 2017.

14. Mariano, D. J., Santos, R. F.; Brito, W. G.; Urbanetz Junior, J.; Casagrande Junior, F. E.. Hydro, thermal and photovoltaic power plants: A comparison between electric power generation, environmental impacts and $\mathrm{CO} 2$ emissions in the Brazilian scenario. Energy environment. v. 7, Issue 4, p.347-356. 2016.

15. Sahu, Alok; Yadav, Neha; Sudhakar, K. Floating photovoltaic power plant: A review. Renewable and Sustainable Energy Reviews, [s.l.], v. 66, p.815-824, dez. 2016. Elsevier BV. http://dx.doi.org/10.1016/j.rser.2016.08.051.

16. Mckay Abe. Floatovoltaics: Quantifying the Benefits of a Hydro-Solar Power Fusion. Bachelor of Arts Degree in Environmental. Pomona 2013.

17. Choi, Young-kwan. A Study on Power Generation Analysis of Floating PV System Considering Environmental Impact. International Journal of Software Engineering and Its Applications, [s.l.], v. 8, n. 1, p.75-84, 31 jan. 2014. Science and Engineering Research Support Society. http://dx.doi.org/10.14257/ijseia.2014.8.1.07.

18. Urbanetz Jr, J. Dimensionamento de sistemas fotovoltaicos. Curitiba, p. 11. 2015.

19. Pereira, E. B.; Martins, F. R.; Gonçalvez, A. R.; Costa, R. S.; Lima, F. J. L.de.; Rüther, R.; Abreu, S. L. De.; Tiepolo, G. M.; Pereira, S. V.; Souza, J. G. De. Atlas Brasileiro de Energia Solar. $2^{\mathrm{a}}$ edição. São José dos Campos: 2017.

20. Pinho, João T.; Galdino, Marco A.; Grupo de Trabalho de Energia Solar (GTES). CEPEL GTES. Manual de engenharia para sistemas fotovoltaicos. Rio de Janeiro, 2014, 529 p.

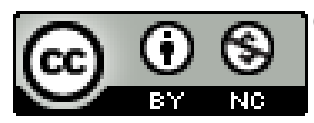

(c) 2018 by the authors. Submitted for possible open access publication under the terms and conditions of the Creative Commons Attribution (CC BY NC) license (http://creativecommons.org/licenses/by-nc/4.0/). 